\title{
Effect of Biochar, Mulch and Ppfm Spray on Leaf Relative Water Content, Leaf Proline, Chlorophyll Stability Index and Yield of Cotton under Moisture Stress Condition
}

\author{
V. Kannan ${ }^{*}$, G. Srinivasan ${ }^{4}$, R. Babu ${ }^{2}$, S. Thiyageshwari ${ }^{3}$ and T. Sivakumar ${ }^{5}$ \\ ${ }^{1}$ Department of Agronomy, ${ }^{2}$ Department of Farm Management, ${ }^{3}$ Department of Soils and \\ Environment, AC \& RI, Madurai, Tamil Nadu, India \\ ${ }^{4}$ Department of Agronomy, ADAC \& RI, Trichy, Tamil Nadu, India \\ ${ }^{5}$ Department of Crop Physiology, TNAU, Coimbatore, Tamil Nadu, India \\ *Corresponding author
}

\section{A B S T R A C T}

Water deficit is one of the major abiotic stresses which adversely affect the crop growth and yield. Moisture stress induce the metabolic functions, such as reduced synthesis of photosynthetic pigments, accumulation of osmoprotectants like proline, decline in the

\section{Keywords}

Moisture, Chlorophyll, Stress, Cotton.

Article Info

Accepted: 04 May 2017 Available Online: 10 June 2017 Chlorophyll stability and alterations in physiological parameters. The Field experiment was conducted at Agricultural College and Research Institute, Madurai during summer season 2016 with the variety of SVPR - 4. To study the effect of moisture stress regimes on physiological parameters of Relative Leaf Water Content (RLWC), Chlorophyll Stability Index (CSI), Proline accumulation in leaf and Seed cotton yield. Experiment was laid out in split plot design with three replications. Moisture regimes were assigned to the main plots viz., Irrigation at IW/CPE ratio to 0.4 (I1) and 0.8 (I2). The subplot comprises with moisture management practices with Biochar application viz., B1-Cotton stalk biochar@5 t ha-1, B2-Cotton stalk biochar@5 t ha ${ }^{-1}+$ Crop residue mulch@ $5 \mathrm{t} \mathrm{ha}^{-1}$, B3-Cotton stalk biochar@ $5 \mathrm{t} \mathrm{ha}^{-1}+$ Crop residue mulch@ $5 \mathrm{tha}^{-1}+$ PPFM @ $500 \mathrm{ml} \mathrm{ha}^{-1}$ on 75 and 90 DAS, B4- Prosophis biochar@ $5 \mathrm{t} \mathrm{ha}^{-1}$, B5- Prosophis biochar@ $5 \mathrm{t} \mathrm{ha}^{-1}+$ Crop residue mulch@5 tha ${ }^{-1}$, B6 - Prosophis biochar@ $5 \mathrm{t} \mathrm{ha}^{-1}+$ Crop residue mulch @ $5 \mathrm{t} \mathrm{ha}^{-1}+$ PPFM@ $500 \mathrm{ml} \mathrm{ha}^{-1}$ on 75 and 90 DAS and B7 - Control. The results of this study showed that RLWC and CSI of cotton were recorded higher and lower for Leaf accumulated Proline under irrigation at IW/CPE to 0.8 (I2) and Prosophis biochar @ $5 \mathrm{t}$ $\mathrm{ha}^{-1}+$ Crop residue mulch @ 5 tha-1 + PPFM @ $500 \mathrm{ml} \mathrm{ha}^{-1}$ on 75 and 90 DAS (B6). The same registered for higher values of crop yield.

\section{Introduction}

Cotton cultivation is a very important part of the Indian agrarian landscape and provides sustainable livelihood to a sizeable population in India devotes more land to cotton than any other country in the world and today ranks first in area with $11.88 \mathrm{~m} \mathrm{ha}^{-1}$ accounting 30 per cent of world coverage and 22 per cent
(351 lakh bales of lint) of the world cotton production and productivity of $568.29 \mathrm{~kg} \mathrm{ha}^{-1}$ (Cotton Advisory Board, 2017). It is estimated that more than 5.8 million farmers cultivate cotton in India and about 40-50 million people are employed directly or indirectly by the cotton industry. Considering 
this importance of cotton crop different attempts have been made to boost up its production.

Cotton is best grown in soils with an excellent water holding capacity. Aeration and good drainage are equally important as the crop cannot withstand excessive moisture and water logging. The moisture stress is the primary cause for the yield reduction in Cotton. Water scarcity and rapid environmental changes force us to find a way to conserve the available soil water and properly manage it for efficient crop production.

In the way Biochar application helps in several ways, by improving soil moisture retention and conserve water, by securing the crops against moisture stress. Biochar is the porous carbonaceous solid produced by thermo chemical conversion of organic materials in oxygen depleted atmosphere (Steinbeiss et al., 2009). With that the adoption of Surface cover with organic mulches is an effective insitu moisture conservation practice and also the PPFM Spray which improve the crop stand to moisture stress. Pink Pigmented Facultative Methylobacteria (PPFM) release the osmoprotectants (sugars and alcohols) on the surface of host plants. This matrix may help protect the plants from desiccation and high temperatures. Keeping this in view, an attempt was made to study the effect of biochar, mulch and PPFM spray on agronomic response of cotton under moisture stress condition.

The physiological parameters such as Relative leaf water content (RLWC; Gadallah, 1995), Leaf proline accumulation (Yancey et al., 1982) and Chlorophyll stability index (CSI; El-Sharkawi and Salama, 1977) are some sensitive physiological indicators used to study the response of plants under moisture stress condition.
The RLWC is a measure of the amount of water present in the leaf tissue. Sampathkumar (2003) reported that cotton plants irrigated at $100 \%$ pan evaporation maintained higher RLWC than moisturestressed plants. Kar et al., (2004) studied the response of different cotton cultivars to moisture stress and found that stress apparently increased the proline accumulation. The stability of chlorophyll under moisture stress was expressed as CSI. Moisture stress damaged the cell membrane and affected the stability of chlorophyll (Blackman et al., 1995).

\section{Materials and Methods}

The field experiment was carried out at Central Farm, Department of Farm Management, Agricultural College and Research Institute, Madurai during Summer 2016. The experimental site falls under the Southern agro-climatic sub-zone of Tamil $\mathrm{Nadu}$ and located at $9^{\circ} 54^{\prime} \mathrm{N}$ latitude and $78^{\circ} 80^{\prime} \mathrm{E}$ longitude at an altitude of $147 \mathrm{~m}$ above mean sea level. The mean annual rainfall is $786.6 \mathrm{~mm}$ in 40 rainy days. The mean maximum and minimum temperature of the location are $33.4^{\circ} \mathrm{C}$ and $23.6^{\circ} \mathrm{C}$ respectively. The relative humidity ranges from 60 to 80 per cent. The soil of the experimental plot was Sandy clay loam in texture, Neutral in $\mathrm{pH}$, medium in organic carbon, low in available nitrogen, medium in available phosphorus and high in available potassium. During Summer season of 2016, the total rainfall received was $172 \mathrm{~mm}$ in 10 rainy days. The average maximum and minimum temperatures during cropping period were $37.01{ }^{\circ} \mathrm{C}$ and $21.6^{\circ} \mathrm{C}$ respectively. The experiment was laid out in Split plot design, replicated thrice with test variety SVPR 4.

The main plots consist of two different moisture regimes viz., I1- IW/CPE ratio of 
0.4 and I2- IW/CPE ratio of 0.8 and Moisture management practices with Biochar application in subplots viz., B1-Cotton stalk biochar (CSB) alone @ $5 \mathrm{t} \mathrm{ha}^{-1}$, B2-Cotton stalk biochar@5 t ha ${ }^{-1}+$ Crop Residue Mulch (CRM)@5 t ha ${ }^{-1}$, B3-Cotton stalk biochar@5 tha ${ }^{-1}+$ Crop residue mulch@5t $\mathrm{ha}^{-1}$ + PPFM @ $500 \mathrm{ml} \mathrm{ha}^{-1}$ on 75 and 90 DAS, B4- Prosophis biochar alone @ $5 \mathrm{tha}^{-1}$, B5- Prosophis biochar @ $5 \mathrm{t} \mathrm{ha}^{-1}+$ Crop residue mulch@5 t ha ${ }^{-1}$, B6 - Prosophis biochar@5 tha ${ }^{-1}+$ Crop residue mulch@5 t $\mathrm{ha}^{-1}+$ PPFM @ $500 \mathrm{ml} \mathrm{ha}^{-1}$ on 75 and 90 DAS and B7 - Control.

The observations was taken from the five fully expanded leaves of the treatment plots which is of the canopy fully exposed to sunlight were selected at random and tagged for assessing the physiological parameters. Observations were made before irrigation cycles during at 70, 90 and 105 DAS of cotton crop.

RLWC was estimated from the method suggested by Barrs and Weatherly (1962) and result was expressed in percentage. CSI was assessed according to the method suggested by Murty and Majumder (1962) and result was expressed in percentage. The leaf proline accumulation was estimated by Bates et al., (1973). The quantity of proline in the test sample was calculated with reference to standard curve and expressed in terms of $\mu \mathrm{mol} \mathrm{g}{ }^{-1} \mathrm{FW}$.

The seed cotton yield was obtained from net plot area was shade dried, weighed at each picking and yields of all picking were added and calculated as $\mathrm{kg}$ per plot and then expressed in kilogram per hectare. The data obtained were subjected to statistical analysis and were tested at five per cent level of significance to interpret the treatment differences as suggested by Gomez and Gomez (2010).

\section{Results and Discussion}

It is well known that water stress limits the crop production by reducing yield levels with induced physiological changes inside the crop plants. In this study also water stress had significant effect on crop yield.

\section{Effect of different moisture regimes and moisture conservation practices with biochar on Physiological parameters}

\section{Leaf Relative water content and chlorophyll stability index}

Water deficit had a significant effect on the Relative water content of the leaf. Leaf relative water content (RWC) is an important indicator of water status in plants; it reflects the balance between water supply to the leaf tissue and transpiration rate (Lugojan and Ciulca, 2011). The chlorophyll stability index is an indicative of the maintenance of photosynthetic pigments under moisture stress condition (Ananthi et al., 2013). The results with respect to RLWC and CSI differed significantly with differing moisture regimes and moisture management with biochar application regimes to conserve moisture at different stages of crop growth.

Moisture regimes had profound influence on relative water content of leaf and registered higher values during the flowering (70 DAS) and comparatively less during the later stages of 90 and 105 DAS (Table 1). The earlier 70 DAS of cotton RLWC was higher $80.4 \%$ under Irrigation at IW/CPE ratio to 0.8 (I2) and lower was recorded in irrigation at IW/CPE ratio to 0.4 (I1) with $71.3 \%$. The same trend was followed for the later stages of RLWC with irrigation at IW/CPE ratio to 0.8 (I2) on 90 and 105 DAS with 79.5 and $70.7 \%$ respectively. The lower values were recorded under Irrigation at IW/CPE ratio to 0.4 (I1) at 90 and 105 DAS with 70.3 and 
$65.6 \%$ respectively. The observed significant decrease in RLWC under moisture stressed condition was due to reduced absorption of water from the soil and inability to control water loss through the stomata. Our results are in assenting with the findings of Kumar et al., (2012) and Ananthi et al., (2013).

In the case of CSI the increased levels were recorded with IW/CPE ratio of 0.8 (I2) during 90 and 105 DAS with 57 and $67.59 \%$ respectively (Table 1). A higher CSI helps the plants to withstand moisture stress through better availability of chlorophyll. The sufficient moisture level in the plant root zone might be the reason for higher CSI (Sampathkumar et al., 2014). Among the moisture conservation practices with biochar application Prosophis biochar with crop residue mulch at 5t/ha + Foliar application of PPFM (500 ml/ha) at 75 and 90 DAS (B6) recorded for the higher RLWC of 80.1 and $74.1 \%$ at 90 and 105 DAS respectively. The same treatment recorded for higher CSI at 90 and 105 DAS with respectively. Which is comparable with Prosophis biochar with crop residue mulch at 5t/ha (B5) at 90 and 105 DAS for RLWC and CSI. This was due to the addition of biochar in soil, which have the porous nature to hold the soil water content and increased the field capacity (Adrian et al., 2016 and Deng et al., 2016) with that addition of mulch can improvise the soil moisture by arresting evaporation with modified microclimate levels may reduce the leaf and soil temperature (Bhatt and Khera, 2006; Zhang et al., 2009). In addition to this PPFM spray with that treatment release the osmoprotectants (sugars and alcohols) on the surface of the plants. This matrix may help to protect the plants from desiccation and high temperatures (Madhaiyan et al., 2006).

Table.1 Effect of different moisture regimes and moisture conservation practices with biochar on Leaf Relative water content and chlorophyll stability index

\begin{tabular}{|c|c|c|c|c|c|c|c|}
\hline \multirow{2}{*}{\multicolumn{3}{|c|}{ Treatments }} & \multicolumn{3}{|c|}{ RWC (\%) } & \multicolumn{2}{|c|}{ CSI (\%) } \\
\hline & & & 70 DAS & 90 DAS & 105 DAS & 90 DAS & 105DAS \\
\hline \multicolumn{8}{|c|}{ Moisture Regimes } \\
\hline $\mathbf{I}_{1}$ & - & IW/ CPE ratio of 0.4 & 71.3 & 70.7 & 65.6 & 51.5 & 53.26 \\
\hline $\mathbf{I}_{2}$ & - & IW/ CPE ratio of 0.8 & 80.4 & 79.5 & 74.6 & 57.0 & 61.59 \\
\hline & \multicolumn{2}{|c|}{ S.Ed } & 0.57 & 1.23 & 1.08 & 0.57 & 1.12 \\
\hline & \multicolumn{2}{|c|}{$\mathrm{CD}(\mathrm{p}=0.05)$} & 2.47 & 5.30 & 4.63 & 2.48 & 4.82 \\
\hline \multicolumn{8}{|c|}{ Moisture Conservation Practices } \\
\hline B1 & - & CSB & 71.9 & 71.1 & 66.9 & 51.6 & 55.3 \\
\hline B2 & - & $\mathrm{CSB}+\mathrm{CRM}$ & 77.6 & 76.5 & 71.1 & 53.7 & 56.6 \\
\hline B3 & - & CSB+CRM+PPFM on 75 and 90 DAS & 77.4 & 78.0 & 72.4 & 55.9 & 57.7 \\
\hline B4 & - & PB & 75.6 & 73.5 & 68.8 & 52.7 & 57.6 \\
\hline B5 & - & $\mathrm{PB}+\mathrm{CRM}$ & 79.2 & 78.7 & 73.3 & 57.9 & 59.4 \\
\hline B6 & - & $\mathrm{PB}+\mathrm{CRM}+\mathrm{PPFM}$ on 75 and $90 \mathrm{DAS}$ & 79.3 & 80.1 & 74.7 & 59.8 & 62.0 \\
\hline \multirow[t]{3}{*}{ B7 } & - & B7-Control & 70.2 & 67.8 & 63.5 & 47.9 & 53.4 \\
\hline & \multicolumn{2}{|c|}{ S.Ed } & 1.23 & 0.99 & 0.99 & 1.09 & 1.30 \\
\hline & \multicolumn{2}{|c|}{$\mathrm{CD}(\mathrm{p}=0.05)$} & 2.54 & 2.05 & 2.06 & 2.26 & 2.69 \\
\hline \multicolumn{8}{|c|}{ Interaction : $\mathbf{I} \times \mathbf{B}$} \\
\hline & \multicolumn{2}{|c|}{ S.Ed } & 1.70 & 1.79 & 1.69 & 1.55 & 2.04 \\
\hline & \multicolumn{2}{|c|}{$\mathrm{CD}(\mathrm{p}=0.05)$} & 3.96 & 5.58 & 5.02 & 3.68 & 5.59 \\
\hline
\end{tabular}

*CSB- Cotton Stalk Biochar, CRM- Crop Residue Mulch,

PPFM-Pink Pigmented Facultative Methylobacteria, PB - Prosophis biochar 
Table.2 Effect of different moisture regimes and moisture conservation practices With biochar on Leaf proline accumulation

\begin{tabular}{|c|c|c|c|c|}
\hline \multirow{2}{*}{\multicolumn{2}{|c|}{ Treatments }} & \multicolumn{3}{|c|}{ PROLINE $\left(\mu \mathrm{mol} \mathrm{g}^{-1} \mathrm{FW}\right)$} \\
\hline & & 70 DAS & 90 DAS & 105 DAS \\
\hline \multicolumn{5}{|c|}{ Moisture Regimes } \\
\hline $\mathbf{I}_{1}$ & \begin{tabular}{|l|l|}
- & IW/ CPE ratio of 0.4 \\
\end{tabular} & 12.04 & 13.63 & 11.47 \\
\hline \multirow[t]{3}{*}{$\mathbf{I}_{2}$} & \begin{tabular}{|l|l|}
- & IW/ CPE ratio of 0.8 \\
\end{tabular} & 7.13 & 6.74 & 5.49 \\
\hline & S.Ed & 0.45 & 0.07 & 0.32 \\
\hline & $\mathrm{CD}(\mathrm{p}=0.05)$ & 1.95 & 0.31 & 1.39 \\
\hline \multicolumn{5}{|c|}{ Moisture Conservation Practices } \\
\hline B1 & \begin{tabular}{|l|l|}
- & CSB \\
\end{tabular} & 10.38 & 10.83 & 10.53 \\
\hline B2 & - $\mathrm{CSB}+\mathrm{CRM}$ & 8.83 & 10.28 & 7.37 \\
\hline B3 & \begin{tabular}{|l|l}
- & CSB+CRM+PPFM on 75 and 90 DAS \\
\end{tabular} & 8.83 & 9.93 & 6.82 \\
\hline B4 & $-\mathrm{PB}$ & 9.60 & 10.18 & 9.62 \\
\hline B5 & \begin{tabular}{|l|}
$-P B+C R M$ \\
\end{tabular} & 8.73 & 9.65 & 7.13 \\
\hline B6 & - - PB+CRM+PPFM on 75 and 90 DAS & 8.76 & 8.13 & 5.85 \\
\hline \multirow[t]{3}{*}{ B7 } & \begin{tabular}{|l|l|} 
- B7-Control \\
\end{tabular} & 11.90 & 12.31 & 12.05 \\
\hline & S.Ed & 0.75 & 0.56 & 0.48 \\
\hline & $\mathrm{CD}(\mathrm{p}=0.05)$ & 1.55 & 1.16 & 0.99 \\
\hline \multicolumn{5}{|c|}{ Interaction : I $\times \mathbf{B}$} \\
\hline & S.Ed & NS & 0.74 & 0.71 \\
\hline & $\mathrm{CD}(\mathrm{p}=0.05)$ & NS & 1.54 & 1.79 \\
\hline
\end{tabular}

*CSB- Cotton Stalk Biochar, CRM- Crop Residue Mulch, PPFM-Pink Pigmented Facultative Methylobacteria, PB - Prosophis biochar

Table.3 Effect of different moisture regimes and moisture conservation practices With biochar on Seed cotton yield

\begin{tabular}{|c|c|c|}
\hline \multicolumn{2}{|c|}{ Treatments } & Seed cotton yield $(\mathrm{kg} / \mathrm{ha})$ \\
\hline \multicolumn{3}{|c|}{ Moisture Regimes } \\
\hline $\mathbf{I}_{1}$ & \begin{tabular}{l|l}
- & IW/ CPE ratio of 0.4
\end{tabular} & 1294 \\
\hline $\mathbf{I}_{2}$ & \begin{tabular}{l|l}
- & IW/ CPE ratio of 0.8 \\
\end{tabular} & 1411 \\
\hline \multicolumn{2}{|r|}{ S.Ed } & 32 \\
\hline & $\mathrm{CD}(\mathrm{p}=0.05)$ & 137 \\
\hline \multicolumn{3}{|c|}{ Moisture Conservation Practices } \\
\hline B1 & \begin{tabular}{l|l|}
- & CSB \\
\end{tabular} & 1294 \\
\hline $\mathrm{B} 2$ & \begin{tabular}{l|l} 
- & CSB+CRM \\
\end{tabular} & 1411 \\
\hline B3 & - CSB+CRM+PPFM on 75 and 90 DAS & 1517 \\
\hline B4 & \begin{tabular}{l|l}
- & PB \\
\end{tabular} & 1439 \\
\hline B5 & \begin{tabular}{l|l} 
& $\mathrm{PB}+\mathrm{CRM}$ \\
\end{tabular} & 1720 \\
\hline B6 & - $\mathrm{PB}+\mathrm{CRM}+\mathrm{PPFM}$ on 75 and $90 \mathrm{DAS}$ & 1836 \\
\hline \multirow[t]{3}{*}{ B7 } & \begin{tabular}{l|l} 
- & B7-Control \\
\end{tabular} & 1084 \\
\hline & S.Ed & 48 \\
\hline & $\mathrm{CD}(\mathrm{p}=0.05)$ & 100 \\
\hline \multicolumn{3}{|c|}{ Interaction : I $\times \mathrm{B}$} \\
\hline & S.Ed & 71 \\
\hline & $\mathrm{CD}(\mathrm{p}=0.05)$ & 178 \\
\hline
\end{tabular}

*CSB- Cotton Stalk Biochar, CRM- Crop Residue Mulch,

PPFM-Pink Pigmented Facultative Methylobacteria, PB - Prosophis biochar 


\section{Leaf proline accumulation}

Water stress induces a significant decrease in metabolic factors such as decrease in chlorophyll content and enhanced accumulation of proline (Din et al., 2011). Accumulation of proline is a widespread plant response to environmental stress, including low water potential. Proline accumulation is believed to play adaptive roles in plant stress tolerance (Ashraf and Fooland, 2007).

Moisture regimes had a positive increase in the Leaf accumulated Proline levels. When the moisture stress was getting high the proline levels also recorded high. The moisture regime irrigated at IW/CPE ratio to 0.4 recorded for high levels of Proline in 70, 90 and 105 DAS with 12.04, 13.63 and 11.47 $\mu$ mol $\mathrm{g}^{-1} \quad$ FW respectively (Table 2). Minimum amount of proline was noticed with the irrigation at IW/CPE to 0.8. In the case of moisture conservation practices with biochar application Prosophis biochar with crop residue mulch at $5 \mathrm{t} / \mathrm{ha}+$ Foliar application of PPFM (500 ml/ha) at 75 and 90 DAS (B6) recorded for the lower levels of proline at 90 and 105 DAS. This was comparable with Prosophis biochar with crop residue mulch at 5t/ha (B5).

Proline content of leaves increased with decline in irrigation water inferred that the production of proline is probably a common response of crops under water-stressed condition. The accumulation of free proline in stressed plants has been found to be an adaptive mechanism for drought tolerance and a positive correlation between magnitudes of free proline accumulation. In this study also moisture stressed treatments recorded the higher proline levels. This is in conformity with the findings of Lobato et al., (2008), Sampathkumar et al., (2013) and Krishnaprabhu et al., (2016).
Effect of different moisture regimes and moisture conservation practices on seed cotton yield

Moisture stress made significant yield differences between the treatments. Irrigations at IW/CPE ratio to 0.8 produced significantly higher seed cotton yield of $1619 \mathrm{~kg} / \mathrm{ha}$ over Irrigation at IW/CPE ratio to 0.4 reached $1325 \mathrm{~kg} / \mathrm{ha}$ (Table 3). The increase in seed cotton yield could be attributed to greater and consistent available soil moisture due to increased level of irrigation that resulted in better crop growth yield and physiological components. In case of moisture conservation practices with biochar application Prosophis biochar with crop residue mulch at $5 \mathrm{t} / \mathrm{ha}+$ Foliar application of PPFM $(500 \mathrm{ml} / \mathrm{ha})$ at 75 and 90 DAS (B6) recorded for higher seed cotton yield $1836 \mathrm{~kg} / \mathrm{ha}$.

In combination, the Irrigation at IW/CPE ratio to 0.8 and Prosophis biochar with crop residue mulch at $5 \mathrm{t} / \mathrm{ha}+$ Foliar application of PPFM $(500 \mathrm{ml} / \mathrm{ha})$ at 75 and 90 DAS recorded higher seed cotton yield. This was evidenced from the values recorded for critical physiological characters, viz. RLWC, proline accumulation in leaf and CSI.

In conclusion, the higher RLWC and CSI indicates the better availability of water in the cell, which increase the photosynthetic rate, dry matter production and high productivity. Also the higher range of proline content in leaves was recorded under moisture stressed treatments, suggesting that the production of proline is probably a common response of crops under water-stressed condition. Under moisture stressed regime irrigation at IW/CPE to 0.4 (I1) is well managed with Prosophis biochar with crop residue mulch at $5 \mathrm{t} / \mathrm{ha}$ and in addition Foliar application of PPFM (500 $\mathrm{ml} / \mathrm{ha}$ ) at 75 and 90 DAS (B6) for the better yield. 


\section{References}

Adrian, M., M. Bass, I. Bird, K. Gavin and M. Brian. 2016. Soil properties, greenhouse gas emissions and crop yield under compost, biochar and co-composted biochar in two tropical agronomic systems. Sci. Total Environ. 550: 45970 .

Ananthi, K., H. Vijayaraghavan, M. Karuppaiya and T. Anand. 2013. Drought-induced changes in chlorophyll stability index, relative water content and yield of cotton genotypes, Insight Botany 3 (1), 1-5.

Ashraf, M and M. R. Fooland. 2007. Roles of glycine betaine and proline in improving plant abiotic stress resistance. Environmental and Experimental Botany, 59(2): 206-216.

Barrs, H.D. and P.E.Weatherly. 1962. A reexamination of relative turgidity for estimating water deficits in leaves. Aust. J. Biol. Sci., 15: 413-428.

Bates, L. S., Waldren, R. P. and I. D. Teare. 1973. Rapid determination of free proline for water-stress studies. Plant Soil. 39:205-207.

Bhatt, R. and K.L. Khera. 2006. Effect of tillage and mode of straw mulch application on soil erosion in the sub mountainous tract of Punjab, India. Soil and Tillage Res. 88: 107-115.

Blackman, S. A., R. L. Obendorf and A.C. Leopold. 1995. Desiccation tolerance in developing soybean seeds: the role of stress proteins. Physiologia Plantarum, 93:630-638.

CAB. 2017. Cotton Advisory Board, http://www.cotcrop.gov.in retrieved on 24.04.2017

Deng, B., P. Tammeorg, O. Luukkanen, J.Helenius and M. Starr. 2016. Effects of Acacia seyal and biochar on soil properties and sorghum yield in agroforestry systems in South Sudan.
Agroforest Syst.DOI 10.1007/s10457016- 9914-2.

Din. J, S. U. Khan, I. Ali, and A. R. Gurmani. 2011. Physiological and agronomic response of canola varieties to drought stress. The J. of Animal and Plant Sci., 21: $78-83$.

Gadallah, M. A. A. 1995. Effect of water stress, abscisic acid and proline on cotton plants. Journal of Arid Environment 30:315-325

Gomez, K.A. and A.A. Gomez. 2010. Statistical Procedures for Agricultural Research (2nd ed), John Wiley and Sons, New York, U.S.A.

Kar, M., B.B. Patro, C.R. Sahoo and Hota, B. (2004). Traits related to drought resistance in cotton hybrids. Indian Journal of Plant Physiology. 4:377-380.

Lobato, A. K. S., C. F. Oliveira Neto, R. C. L. Costa, Santos, G. Filho, R. C. L. Cost, F. J. R. Cruz, H. K. B. Neves, and Lopes, M. J. S. 2008. Physiological and biochemical behavior in soybean (Glycine max cv. Sambabia) plants under water deficit. Australian Journal of Crop Science. 2:25-32.

Lugojan C. and S. Ciulca. 2011. Evaluation of Relative Water Content in winter wheat. J. Hortic. Fores. Biotechnol. 15: 173177

Madhaiyan, M., S. Poonguzhali, S.P. Sundaram and T.M. SA. 2006. A newsight into foliar applied methanol influencing phylloplane methylotrophic dynamics and growth promotion of cotton (Gossypium hirsutum L.) and sugarcane (Saccharum officinarum L.). Environmental and Experimental Botany, 57: 168-176.

Murty, K. S. and S. K. Majumder. 1962. Modification of the technique for determination of chlorophyll stability index in relation to studies of drought resistance in rice. Current Sci. 31:470471. 
Sampathkumar, T. 2003. Evaluation of Drip and Surface Irrigation Methods with Rice Straw Mulching in Cotton. M.Sc thesis, Department of Agronomy, Agricultural College and Research Institute, TNAU, Madurai, Tamil Nadu, India.
Sampathkumar, T., B.J. Pandian, P. Jayakumar and Manickasundaram, $\mathrm{P}$. 2014. Effect of Deficit Irrigation On Yield, Relative Leaf Water Content, Leaf Proline Accumulation And Chlorophyll Stability Index Of CottonMaize Cropping Sequence. Expl Agric. 50 (3): 407-425.

\section{How to cite this article:}

Kannan, V., G. Srinivasan, R. Babu, S. Thiyageshwari and Sivakumar, T. 2017. Effect of Biochar, Mulch and Ppfm Spray on Leaf Relative Water Content, Leaf Proline, Chlorophyll Stability Index and Yield of Cotton under Moisture Stress Condition. Int.J.Curr.Microbiol.App.Sci. 6(6): 604-611. doi: https://doi.org/10.20546/ijcmas.2017.606.071 